\title{
Tatsiana Serada
}

- Polotsk State University

- e-mail: t.sereda@psu.by

- ORCID: 0000-0003-3859-2382

\section{Elvira Varanko}

- Polotsk State University

- e-mail: e.voronko@psu.by

- ORCID: 0000-0003-4278-9217

\section{IMPROVING THE QUALITY OF EDUCATION BY INTEGRATING NETWORK UNIVERSITIES AND BUSINESS}

\section{Abstract}

- Goal - this article's main goal is to show the need for the integration of universities on the basis of the processes of network interaction between business and education as one of the conditions for improving the quality of education in the country, and accordingly the index of education and the human development index of the country.

- Research methodology - the authors used analytical, economic, statistical methods of data analysis, conceptual and empirical research.

- Score/results - the article reveals the essence and substantiates the need to implement of the practice-oriented education system by using the dual training system and creating of network interaction between universities in different countries. The advantages of such a model are revealed in comparison with the traditional form of training for the employer, educational institution, future specialist and the state. The instruments and forms of development of trilateral integration are described.

- Originality/value - the article presents the results of a comparative study of the human development of Belarus and its four neighbouring countries (Poland, Lithuania, Russia, Ukraine), has theoretical and practical significance, contains the author's generalizations and conclusions.

| Key words: integration, education, education index, human development index, life expectancy index, income index, global happiness index, network university, dual learning. 


\section{Introduction}

Education is an essential component of the indicator "quality of life". Therefore, improving the quality of education is one of the urgent problems of the development of the education system and modern society. At present, society requires new knowledge; new methods and models for their acquisition are also needed. Today, enterprises require specialists who will be capable of self-fulfillment, socially mobile, able to develop and change their own life strategies, and are easily adaptable to the current economic development of the respective country. One of the ways to increase the intellectual potential in the country by improving the quality system of educational services may be to combine the efforts of universities in different countries and businesses through network integration.

\section{Analysis of the human development of Belarus and neighbouring countries}

The main strategic tool of the concept of human development is the Human Development Index, which reflects the situation in the country in terms of the health status, education and income of its citizens. The level of the Human Development Index (HDI) is determined by the level of the education index, life expectancy index and gross national income index.

Chart 1. Human Development Index Dynamics, 2010-2018

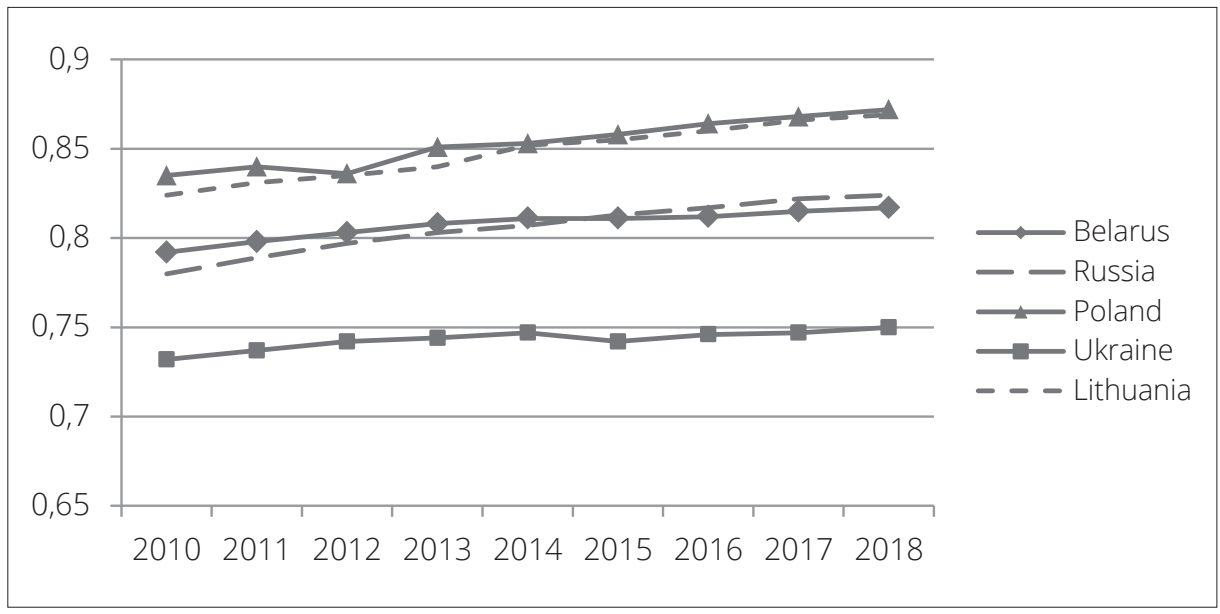

Source: bompiled by the authors based Human Development Reports (1998-2019). 
A study of the quality of life in Belarus and its neighbouring countries, which are also the north-eastern neighbours of Poland, showed that for more than 20 years the standard of living of the population has been growing (Chart 1).

The Republic of Belarus has the highest growth rate of the analyzed indicator; in Ukraine, living standards are growing at a slower pace. Raising the rating helps to find all countries, with the exception of Ukraine, in the group of countries with a high level of development. The 2018 rating covers 189 states and jurisdictions; the 1998 rating is 174 (Table 1).

Table 1. Human Development Index

\begin{tabular}{|l|c|c|c|c|c|c|c|c|}
\hline \multirow{2}{*}{ Country } & \multicolumn{4}{|c|}{ Indicator value } & $\begin{array}{c}\text { Growth rate } \\
2018 / 1998\end{array}$ & \multicolumn{2}{c|}{ Rating } \\
\cline { 2 - 10 } & 1998 & 2003 & 2008 & 2013 & 2018 & $\%)$ & 1998 & 2018 \\
\hline Poland & 0,769 & 0,804 & 0,824 & 0,851 & 0,872 & 113,39 & 44 & 32 \\
\hline Lithuania & 0,736 & 0,790 & 0,831 & 0,840 & 0,869 & 118,07 & 52 & 34 \\
\hline Russia & 0,703 & 0,740 & 0,774 & 0,803 & 0,824 & 117,21 & 62 & 49 \\
\hline Belarus & 0,671 & 0,704 & 0,774 & 0,808 & 0,817 & 121,76 & 57 & 50 \\
\hline Ukraine & 0,665 & 0,699 & 0,733 & 0,744 & 0,750 & 112,78 & 78 & 88 \\
\hline
\end{tabular}

Source: compiled by the authors based Human Development Reports (1998-2019).

Chart 2. Education Index Dynamics

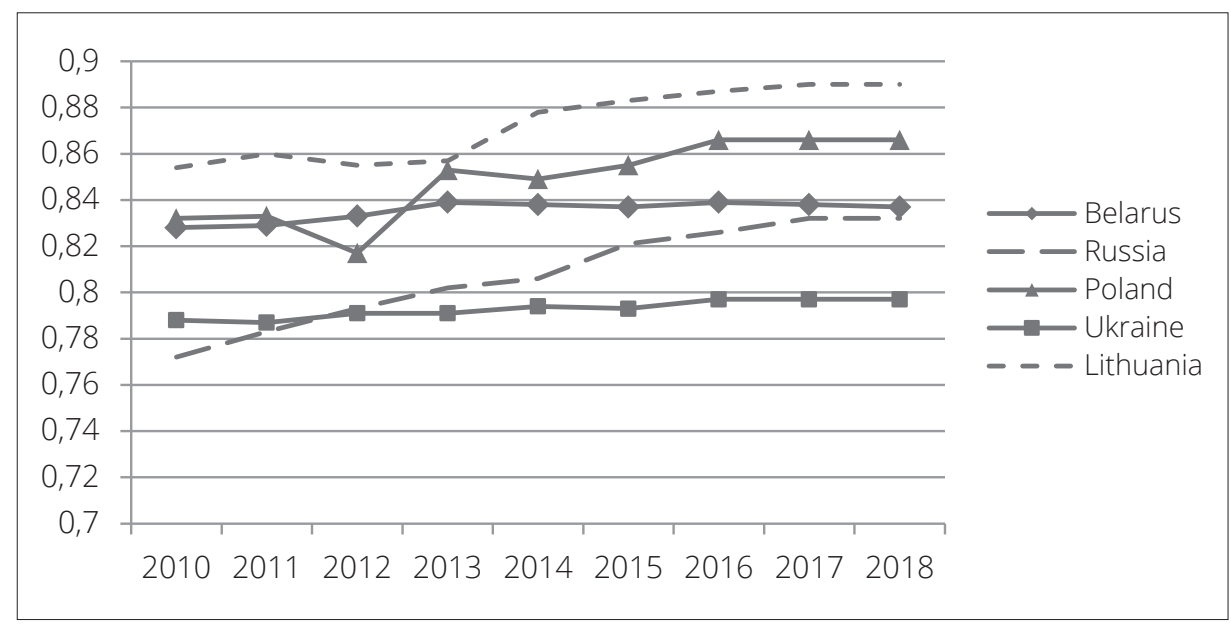

Source: compiled by the authors based Human Development Reports (1998-2019). 
In determining the level of economic development of a country, the key criterion for ranking countries to developed, developing and least developed countries is the Education Index, the dynamics of which are shown in Chart 2.

According to the Human Development Report (1990-2018), the growth rate of the Education Index is faster than the growth rate of the Human Development Index, although systematic growth is not always observed (Table 2).

Table 2. Education Index

\begin{tabular}{|c|c|c|c|c|c|c|}
\hline \multirow{2}{*}{ Country } & \multicolumn{5}{|c|}{ Indicator value } & \multirow{2}{*}{$\begin{array}{c}\text { Growth rate } \\
2018 / 1998(\%)\end{array}$} \\
\hline & 1998 & 2003 & 2008 & 2013 & 2018 & \\
\hline Poland & 0,756 & 0,811 & 0,815 & 0,853 & 0,866 & 114,55 \\
\hline Lithuania & 0,718 & 0,820 & 0,873 & 0,857 & 0,890 & 123,96 \\
\hline Russia & 0,694 & 0,757 & 0,770 & 0,802 & 0,832 & 119,88 \\
\hline Belarus & 0,649 & 0,696 & 0,804 & 0,839 & 0,837 & 128,97 \\
\hline Ukraine & 0,708 & 0,754 & 0,786 & 0,791 & 0,797 & 112,57 \\
\hline
\end{tabular}

Source: compiled by the authors based Human Development Reports (1998-2019).

The Life expectancy index shows the level of longevity and health achieved by a country. A positive trend is the almost systematic growth of this indicator over 20 years (Table 3 ).

Table 3. Life Expectancy Index

\begin{tabular}{|l|c|c|c|c|c|c|}
\hline & \multicolumn{7}{|c|}{ Indicator value } & Growth rate \\
\cline { 2 - 6 } Country & 1998 & 2003 & 2008 & 2013 & 2018 & $2018 / 1998(\%)$ \\
\hline Poland & 0,814 & 0,841 & 0,858 & 0,881 & 0,901 & 110,69 \\
\hline Lithuania & 0,775 & 0,793 & 0,802 & 0,833 & 0,858 & 110,71 \\
\hline Russia & 0,699 & 0,694 & 0,730 & 0,777 & 0,806 & 115,31 \\
\hline Belarus & 0,730 & 0,736 & 0,763 & 0,810 & 0,840 & 115,07 \\
\hline Ukraine & 0,728 & 0,728 & 0,743 & 0,783 & 0,799 & 109,75 \\
\hline
\end{tabular}

Source: compiled by the authors based Human Development Reports (1998-2019). 
The Gross National Income Index is one of the components of the Human Development Index. The dynamics of gross national income per capita (in US dollars in 2011), Gross national income (GNI) per capita (2011 PPP \$), is presented in Table 4, the level of the Income Index is shown in Table 5.

Table 4. Gross national income per capita (in US dollars in 2011)

\begin{tabular}{|c|c|c|c|c|c|c|}
\hline & \multicolumn{7}{|c|}{ Indicator value } & Growth rate \\
\cline { 2 - 6 } Country & 1998 & 2003 & 2008 & 2013 & 2018 & $2018 / 1998(\%)$ \\
\hline Poland & 13,230 & 15,631 & 20,031 & 17,006 & 27,626 & 208,81 \\
\hline Lithuania & 11,444 & 15,310 & 22,756 & 24,492 & 29,775 & 260,18 \\
\hline Russia & 11,593 & 16,532 & 23,557 & 24,675 & 25,036 & 215,96 \\
\hline Belarus & 6,829 & 9,088 & 14,809 & 17,006 & 17,039 & 249,51 \\
\hline Ukraine & 4,371 & 6,149 & 8,694 & 8,194 & 7,994 & 182,89 \\
\hline
\end{tabular}

Source: compiled by the authors based Human Development Reports (1998-2019).

Table 5. Income Index

\begin{tabular}{|c|c|c|c|c|c|c|}
\hline \multirow{2}{*}{ Country } & \multicolumn{5}{|c|}{ Indicator value } & \multirow{2}{*}{$\begin{array}{c}\text { Growth rate } \\
2018 / 1998(\%)\end{array}$} \\
\hline & 1998 & 2003 & 2008 & 2013 & 2018 & \\
\hline Poland & 0,738 & 0,763 & 0,801 & 0,820 & 0,849 & 115,04 \\
\hline Lithuania & 0,716 & 0,760 & 0,820 & 0,831 & 0,860 & 120,11 \\
\hline Russia & 0,718 & 0,772 & 0,825 & 0,832 & 0,834 & 116,16 \\
\hline Belarus & 0,638 & 0,681 & 0,755 & 0,776 & 0,776 & 121,63 \\
\hline Ukraine & 0,571 & 0,622 & 0,675 & 0,666 & 0,662 & 115,94 \\
\hline
\end{tabular}

Source: compiled by the authors based Human Development Reports (1998-2019).

To assess the influence of various factors on the value of the human development index, we analyze the presence and strength of the relationship between it and its constituent indices. The results of the analysis are presented in Table 6 (see: the next page). 
Table 6. Correlation analysis of the HDI and its constituent indices for neighboring countries

\begin{tabular}{|c|c|c|c|c|c|}
\hline Name of indicator & 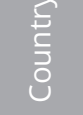 & HDI & $\begin{array}{l}\text { Education } \\
\text { Index }\end{array}$ & $\begin{array}{l}\text { Life expectancy } \\
\text { Index }\end{array}$ & $\begin{array}{l}\text { Income } \\
\text { Index }\end{array}$ \\
\hline HDI & \multirow{4}{*}{$\begin{array}{l}\text { D } \\
\frac{C}{\pi} \\
\frac{\pi}{0} \\
\Omega\end{array}$} & 1 & & & \\
\hline Education Index & & 0,9831 & 1 & & \\
\hline Life expectancy Index & & 0,9992 & 0,9776 & 1 & \\
\hline Income Index & & 0,9892 & 0,9465 & 0,9911 & 1 \\
\hline $\mathrm{HDI}$ & \multirow{4}{*}{ 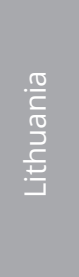 } & 1 & & & \\
\hline Education Index & & 0,9692 & 1 & & \\
\hline Life expectancy Index & & 0,9144 & 0,7959 & 1 & \\
\hline Income Index & & 0,9935 & 0,9463 & 0,9174 & 1 \\
\hline $\mathrm{HDI}$ & \multirow{4}{*}{ 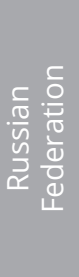 } & 1 & & & \\
\hline Education Index & & 0,9813 & 1 & & \\
\hline Life expectancy Index & & 0,9338 & 0,8813 & 1 & \\
\hline Income Index & & 0,9481 & 0,9265 & 0,7912 & 1 \\
\hline $\mathrm{HDI}$ & \multirow{4}{*}{$\frac{\frac{n}{2}}{\frac{\pi}{d}}$} & 1 & & & \\
\hline Education Index & & 0,9946 & 1 & & \\
\hline Life expectancy Index & & 0,9259 & 0,8828 & 1 & \\
\hline Income Index & & 0,9911 & 0,9983 & 0,8684 & 1 \\
\hline $\mathrm{HDI}$ & \multirow{4}{*}{ 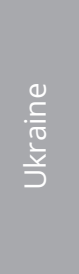 } & 1 & & & \\
\hline Education Index & & 0,9932 & 1 & & \\
\hline Life expectancy Index & & 0,8262 & 0,7618 & 1 & \\
\hline Income Index & & 0,9593 & 0,9772 & 0,6395 & 1 \\
\hline
\end{tabular}

Source: compiled by the authors. 
According to the indicators presented in the table for Poland, there is a strong correlation between the human development index and the index of life expectancy in the country, education and gross national income - 0.9831, 0.9992 and 0.9892, respectively. The same situation holds for the other correlation coefficients.

These tables clearly confirm the presence of a strong correlation between all the analyzed indices and for Lithuania. This is evidenced by the following values of the correlation coefficients:

- the correlation coefficient of human development and education indices (0.9692), human development indices and life expectancy (0.9144), human development index and gross national income index - 0.9935;

- the correlation coefficient of the education index and the index of life expectancy was 0.7959 , and the education index and the gross national income index - 0.9463;

- the correlation coefficient of the indices of life expectancy and gross national income -0.9174 .

The correlation coefficients given in the table for Russia are in the range from 0.7 to 0.99 and indicate a strong relationship between the studied indices. The correlation coefficient for the human development index and the education index is highest at 0.9813 , and the correlation coefficient for gross national income and life expectancy is the lowest (0.7912).

The values of the correlation coefficients show a strong correlation between the studied indices for Belarus:

- the correlation coefficients of the human development index and education indices, expected duration, gross national income are 0.9946, 0.9259 and 0.9911 respectively;

- the correlation coefficients of the education index and the expected duration indices, gross national income are equal to 0.8828 and 0.9983 , respectively;

- the correlation coefficient of the expected duration index and the gross national income index is the lowest and amounts to 0.8684 .

Correlation analysis of indicators in Ukraine characterizes the presence of a relationship between the analyzed indices. However, this relationship is of a different nature:

- for the human development index and education index, human development index and gross national income index, education index and gross national income index, this relationship is very high; 
- the correlation coefficients of human development indices and life expectancy, education indices and life expectancy are 0.8262 and 0.7618 , respectively, and demonstrate a high dependence;

- the gross national income index and the index of life expectancy are characterized by an average level of communication.

Summing up the analysis presented above, we note the following:

1) The highest correlation coefficient (0.9946), reflecting the existence of a connection between the human development index and the education index, is Belarus, and Lithuania has the lowest (0.9692).

2) The highest value of the correlation coefficient between the human development index and the index of life expectancy is demonstrated by Poland (0.9992), the lowest - Ukraine (0.8262).

3) The human development index and gross national income index also show a strong correlation. The highest value of the correlation coefficient between these indices belongs to Lithuania, Russia has the lowest (0.9481) of the analyzed countries the value of this coefficient.

Analyzing the rating of the countries of the world by the level of happiness (The Happy Planet Index), which was first prepared in April 2012 for the UN Conference unfortunately, we note that the residents of Belarus and Ukraine became less happy over time, despite the fact that the level of GDP at per capita (Table 7), in particular in Belarus, increased. In Poland and Lithuania, there have been significant improvements in quality and living standards.

Table 7. Happy Planet Index

\begin{tabular}{|l|c|c|c|c|c|}
\hline \multirow{2}{*}{ Country } & \multicolumn{2}{c|}{ Indicator value } & \multicolumn{3}{c}{ Rating } \\
\cline { 2 - 6 } & 2013 & 2018 & $2018 / 2013(\%)$ & 2013 & 2018 \\
\hline Poland & 5,822 & 6,182 & 106,18 & 51 & 40 \\
\hline Lithuania & 5,426 & 6,149 & 113,32 & 71 & 42 \\
\hline Russia & 5,464 & 5,648 & 103,37 & 68 & 68 \\
\hline Belarus & 5,504 & 5,323 & 96,71 & 66 & 81 \\
\hline Ukraine & 5,057 & 4,332 & 85,66 & 87 & 133 \\
\hline
\end{tabular}

Source: compiled by the authors based Ranking of countries of the world in terms of happiness. 
The achieved values of the above indicators ensure the Polish Republic, Lithuania (since 2011), the Russian Federation (since 2015) and the Republic of Belarus (since 2017) being in a group of countries with a very high level of human development.

\section{Directions for improving the education system}

To maintain and increase the achieved positions along with the development of the economy and society, it is also necessary to improve the education system, since the state can lose or gain educated people, respectively reducing or increasing its intellectual potential. The index of the development of the intellectual potential of a society is an essential component of the index of the development of human potential, therefore increasing the intellectual potential, and with it the quality of education, is becoming a global goal for the development of modern society.

The problems of universities as the main generators of innovations and producers of educational services in such conditions of development are quite extensive. The main problem that the education system needs to solve is to form an optimal model of vocational training that would overcome the lag in the structure, volumes and quality of labor resources from the real requirements of specific enterprises and organizations.

One of the ways to improve the quality of educational services is the creation of network universities by integrating universities and network interaction, which implies the formation of a network of universities that cooperate with each other. This involves the interaction of universities at the level of joint educational programs and research, the competence exchange and strengthening of each individual university by complementing the integral competencies.

The interaction mechanism is quite simple: the use of those competencies that are absent or poorly represented in one's own university.

Specific tools are: joint projects financed by all parties involved in them, joint virtual laboratories, departments, centers that would allow the exchange of scientific research, students, teachers, etc., massive open online courses.

The academic mobility of students, which is one of the highest priority areas of activity of such associations, can be one of the forms of a network association of universities. Facilitating students' access to partner universities is an urgent task for any network organization of higher education. Admission to a network 
university increases the student's chance to take part of the studies at a foreign university, which has a positive effect on both student motivation and the image of the university.

One example of a network university is the Network University of the Commonwealth of Independent States, created in 2008 with the support of the Interstate Fund for Humanitarian Cooperation of the CIS Member States. The CIS Network University consortium includes 27 leading universities from nine countries: the Republic of Armenia, the Azerbaijan Republic, the Republic of Belarus, the Republic of Kazakhstan, the Kyrgyz Republic, the Republic of Moldova, the Russian Federation, the Republic of Tajikistan and Ukraine. The aim of the project is to improve the quality of higher education and its attractiveness, the development of cooperation and inter-university relations in the CIS ${ }^{1}$. In 2013, the "Network of Frontier Universities" was created, which initially included 3 universities of the Republic of Belarus, 3 universities of the Russian Federation, 2 universities of Ukraine, 1 Polish and 1 Lithuanian universities ${ }^{2}$. Such projects contribute to the joint positioning of universities in the international arena, strengthen the interaction of universities at the level of joint educational programs and research, and increase the image and prestige of the education system.

The key point in the development of the modern system of higher education is the interaction of universities and business. The active participation of employing companies in the process of training future specialists is a necessary and prerequisite. Such cooperation complements the process of fundamental academic preparation with practical knowledge and skills in the field of modern and advanced technologies, elements of management, business and corporate culture, business communication skills, etc., adapting the graduate to the real conditions of his future work. Practical orientation allows students to acquire the necessary minimum of professional skills, experience in organizational work, a system of theoretical knowledge, professional mobility and competence. The practice of employing graduates in recent years shows that potential employers in the selection of personnel express interest in personnel who already have, in addition to special education, work experience [Sereda, 2018: 426].

1 Compiled by the authors based on the materials of the Official website "Network University of the Commonwealth of Independent States".

2 Compiled by the authors based on the materials of the Official website "Border University Network". 
Strengthening the practice-oriented education involves the use of a dual system of vocational training, which has received international recognition as a form of training. The essence of dual training is a balanced combination of theory and practice through the cooperation of enterprises, educational institutions, and authorities.

The introduction of the dual training system provides significant advantages for the employer, for the educational institution, for the future specialist and for the state, which effectively solves the problem of training qualified personnel for its economy. The advantages of the dual training system (compared with the traditional form of training) include [Voronko, Sereda, 2018: 72]:

- strengthening the practice-oriented educational process, while maintaining the level of the theoretical component;

- training of specialists in accordance with the real needs of employers, which contributes to the employment of a significant number of graduates due to the needs of employers;

- the formation of professional, social, organizational, psychophysiological adaptation by influencing the personality of a specialist in the process of practical training at the enterprise;

- ensuring higher motivation of students in obtaining knowledge, due to the high-quality performance of official duties at the workplace;

- saving financial resources for the selection and selection of personnel increases the interest of employers in the education and training of their future employees;

- the concentration of the institution on the transfer of fundamental knowledge, allows to increase not only the mobility of the graduate in the professional direction, but also makes him competitive in the modern labor market;

- reduction of budget costs for training specialists, co-financing of the training process by the business;

- increasing the material, technical and technological equipment of the educational process;

- realization by students of the possibilities of independent financial support during their education.

The most relevant today are the associative forms of integration of universities based on the processes of network interaction between a sufficiently large number of sectors representing science, education and business: universities, state scientific organizations, small high-tech companies, large businesses. This form 
of partnership is more complex than cooperation between individual scientific organizations and private enterprises.

In the interaction of universities and enterprises, it is advisable to use active forms of participation of existing specialists and experts of enterprises in the educational process.

The main forms of such interaction are:

- the participation of employers in the formation of curricula and training programs for specialists;

- organization of Internship and graduate design of students in the partner organization;

- targeted training for specialists of the partner organization;

- use of personnel and scientific and technical potential of partner organization in the educational process, including through the creation of branches of departments;

- development and implementation together with students of integrated, interdisciplinary, professional projects that subsequently go into graduation theses;

- the use of remote interactive forms of organization of the educational process, the creation of conditions for students to carry out labor activities according to the profile of the specialty while studying at the university.

\section{Conclusions}

The use of network interaction in conjunction with practice-oriented, solves several problems at the same time: it improves the quality and image of professional education, increases the motivation of students, reduces the shortage of highly qualified workers. The high reliability of such a system is explained by the fact that it meets the interests of all parties involved (business, educational institution, enterprises, students, and the state).

The integration between network universities and business allows us to modernize the educational process taking into account the requirements of the labor market for specialists. The formation of partnerships between the education system and the labor market contributes to an increase in the efficiency of the educational process, the successful employment of university graduates, gives greater stability to the system of knowledge generation and transfer, and ensures their diffusion. 
The results of the study showed the increasing relevance of the development of trilateral integration in the educational environment and the need to intensify these projects.

\section{| References}

Human Development Reports (1998-2019). United nations development programme, [online] http://hdr.undp.org/en/data [date of access: 05.02.2020].

Official site "Network University of the Commonwealth of Independent States", [online] http://imp.rudn.ru/su_sng/index.html [date of access: 10.02.2020].

Official site "Border University Network", [online] https://sup.uwb.edu.pl/en [date of access: 10.02.2020].

Sereda T.N., 2018, The formation of a practice-oriented educational environment of the university, Innovative approaches in the educational process of higher education: national and international aspects: an electronic collection of articles of an international scientific and practical conference dedicated to the 50th anniversary of Polotsk State University, p. 426-430, [online] http://elib.psu.by:8080/ hanVoronko E.N., Sereda T.N., 2018, Dual training as a condition for increasing career guidance and competitiveness of future economists, "Bulletin of Polotsk State University. Series D. Economic and legal sciences", No. 13, p. 70-74, [online] http://elib.psu.by:8080/handle/123456789/23184 [date of access: 5.02.2020]. dle/123456789/21486 [date of access: 3.02.2020].

World Happiness Report, 2012, UN Sustainable Development Solutions Network, [online] https://gtmarket.ru/ratings/world-happiness-report [date of access: 7.02.2020]. 